\title{
Spironucleus vortens, a possible cause of hole-in-the-head disease in cichlids
}

\author{
Gregory C. Paull*, R. A. Matthews \\ Department of Biological Sciences, University of Plymouth, Plymouth, Devon PL4 8AA, United Kingdom
}

\begin{abstract}
Hole-in-the-head disease is recorded in 11 discus Symphysodon discus Heckel, 1840 and 1 angelfish Pterophyllum scalare Lichtenstein, 1823 obtained from local aquarists within the Southwest of the UK. Spironucleus vortens Poynton et al. 1995, was isolated from the kidney, liver, spleen and head lesions of discus showing severe signs of the disease and from the intestines of all fish. The hexamitid was also recorded from the head lesions of the angelfish. The identity of these flagellates was confirmed as $S$. vortens on the basis of topographical features seen with the aid of SEM. A modified in vitro culture method was successfully developed for the detection, isolation and long-term maintenance of $S$. vortens. The flagellate was sub-cultured at 3 to 5 d intervals, new media being supplemented with fresh liver from Oreochromis niloticus (Linnaeus, 1757) free from infection. The results are discussed in relation to $S$. vortens as the causative agent for hole-in-the-head disease following systemic infection via the digestive tract.
\end{abstract}

KEY WORDS: Hole-in-the-head disease $\cdot$ Cichlids $\cdot$ Spironucleus vortens $\cdot$ In vitro culture Resale or republication not permitted without written consent of the publisher

\section{INTRODUCTION}

Hole-in-the-head disease has been reported from many tropical species of fish including freshwater Anabantidae, Belontidae and Cichlidae, and marine Acanthuridae and Pomacentridae (Becker 1977, Ferguson \& Moccia 1980, Bassleer 1983, Post 1987, Andrews et al. 1988, Gratzek 1988). The disease is commonly recorded in cichlids, namely, angelfish Pterophyllum scalare Lichtenstein, 1823 and discus Symphysodon discus Heckel, 1840. These 2 species are of commercial importance in a global ornamental pet fish industry with an estimated value in excess of US $\$ 7 \times 10^{9}$ each year (Andrews 1990). Becker (1977), Goldstein (1979), and Vickerman (1990) discussed 'hole-in-the-head' disease as an environmental disease, caused by poor husbandry. Flagellated protozoa belonging to Hexamitidae have also been implicated as the causative agents of this disease in tropical fish (Ferguson \& Moccia 1980). These parasites are commonly recorded from the

*E-mail: g.c.paull@cefas.co.uk digestive tracts of cichlids $\mathrm{n}$ additon to cyprinids, eels and salmonids and have been recorded from a wide range of internal organs within these hosts including heart, kidney, liver, spleen, eyes, brain and blood (Becker 1977, Ferguson \& Moccia 1980, Gratzek 1988). In re-appraising the taxonomy of fish hexamitids, Woo \& Poynton (1995) considered topographical features as seen with the aid of SEM, as key elements in the separation of Hexamita and Spironucleus. Such features were used by Poynton et al. (1995) in describing Spironucleus vortens from angelfish, the type host. Very few other species of hexamitids from fish have been studied with the aid of electron microscopy. These include Hexamita salmonis, Moore 1922, from freshwater salmonids (Ferguson 1979, Poynton \& Morrison 1990), Spironucleus torosa Poynton and Morrison 1990, from marine gadids (Poynton \& Morrison 1990) and Spironucleus barkhanus from Arctic char, Salvelinus alpinus (Sterud et al. 1998). Prior to the application of SEM H. salmonis Moore 1922, was recorded from skin lesions of angelfish by Nigrelli \& Hafter (1947) and Spironucleus elegans Lavier 1936 described from the hind-gut of angelfish (Kulda \& Lom 1964a,b). This 
latter species has also been identified from European amphibians with the aid of TEM (Brugerolle et al. 1973).

The present investigation aimed to further our understanding of hole-in-the-head disease in tropical cichlids by isolating, and identifying the organism involved. A modification of Buchmann \& Uldal's (1996) in vitro culture technique for Hexamita salmonis from rainbow trout Oncorhynchus mykiss was used to screen the fish for the presence of flagellates.

\section{MATERIALS AND METHODS}

Source of fish stock, collection and husbandry. Source: A total of 12 mature tropical fish showing different severities of hole-in-the-head disease, from mild to heavy, were obtained from hobbyists and commercial aquarists within the southwest of the UK. These included 11 discus, 10 of which were from a single supplier, and 1 angelfish. One angelfish with no previous record of hole-in-the-head disease was also obtained and this served as a control. The high cost of tropical fish and financial constraints of the project restricted the use of further controls. Oreochromis niloticus (Linnaeus, 1757), naïve to hexamitid infections, were obtained from stock bred within Plymouth University aquarium.

Maintenance of fish: The discus and angelfish were kept either in a re-circulating system with an external mechanical and biological filter, or in static tanks with an internal air-driven sponge filter and polyfilter. Water quality was monitored daily with a C100 series multi-parameter bench spectrophotometer (HannahInstruments) and remained within the parameters suitable for such fish species (Degen 1996). A $10 \%$ water change was carried out for each system every $2 \mathrm{~d}$. The angelfish and discus were kept separately to prevent possible cross infections and fed daily on Gammairradiated frozen bloodworm and mysids, artemia flake food and Tetramin/Aquarium tropical flake food. Oreochromis niloticus were fed commercial trout pellets (Trouw Aquaculture).

Detection of hexamitid flagellates. Investigations were undertaken of the fish surface, intestine and selective organs including the kidney, liver and spleen. Flagellate parasites were detected with the aid of phase contrast microscopy either by examination of tissue squash preparations or following in vitro culture of infected material. Prior to examination of internal organs, fish were killed with an overdose of MS-222 (3-aminobenzoic acid ethyl ester Sigma Cat. No. A5040), a $0.1 \mathrm{ml}$ blood sample was immediately removed from the caudal vein and the fish weighed. At this stage a tissue sample was taken from the head lesions. The fish was then swabbed with $70 \%$ alcohol and selective internal organs removed for further examination using sterile instruments. Signs of gross pathology were recorded and the spleen removed and weighed.

In vitro culture of hexamitids. The in vitro method described by Buchmann \& Uldal (1996) for Hexamita salmonis was used here for screening tropical fish for hexamitids. In the present study bile salts (bovine Sigma B-8381) added at a concentration of 120 to $150 \mathrm{mg} \mathrm{l}^{-1}$ substituted for Keister's TYI-S-33 medium. In addition, the antibiotics penicillin, streptomycin, gentamycin and fungizone were added at $1000 \mu \mathrm{g}$ $\mathrm{ml}^{-1}$. Media were aliquoted into bijou bottles and conveniently stored at $4^{\circ} \mathrm{C}$ until required. Medium used for subculture was supplemented with Oreochromis niloticus liver as a further modification of Buchmann \& Uldal's method. Liver was removed under aseptic conditions from freshly killed fish and an approximate $3 \mathrm{~mm}^{3}$ section added to $3 \mathrm{ml}$ of fresh media. Control cultures included media and fresh liver removed from $O$. niloticus. Flagellates were incubated in the dark at $25^{\circ} \mathrm{C}$ and sub-cultured every 3 to $5 \mathrm{~d}$.

Estimation of flagellates in culture. Cultured flagellates were enumerated in 1 of 2 ways. A simple approach, suitable for determining an appropriate time for sub-culturing, involved categorising the number of parasites per field of view $(\times 40)$ on a zero to +++ scale $\left(+=1\right.$ to 2 field $^{-1},++=10$ to 20 field $^{-1}$ and $+++=$ $>20$ field $^{-1}$ ). For the determination of flagellate growth the culture medium was agitated prior to the removal of two $15 \mu \mathrm{l}$ samples, 1 from the surface and 1 from the bottom. Both samples were pooled in a single vial and the parasites killed with the addition of $15 \mu$ of formalin. Following further agitation, a sample was transferred to a haemocytometer and flagellates enumerated as for white blood cell counts (MacInnis \& Voge 1970).

Microscopic examination of flagellates. Unstained hexamitids inactivated in formalin were investigated directly with the aid of phase contrast microscopy. Giemsa-stained smear preparations of the parasites in culture medium were used to study details of nuclei.

Scanning electron microscopy: A suspension of flagellates in culture was fixed in $2.5 \%$ glutaraldehyde solution at $4^{\circ} \mathrm{C}$ for $1 \mathrm{~h}$. The flagellates were then concentrated by centrifugation at $14300 \mathrm{rpm}(11530 \times \mathrm{g})$ for $30 \mathrm{~s}$ and the pellet resuspended in the same fixative. The suspension was passed through an $8.0 \mu \mathrm{m}$ nucleopore polycarbonate millipore filter. The captured flagellates were then dehydrated in a graded series of alcohol, critically point dried, mounted on stubs and gold coated. The preparations were then viewed using a JEOL 6100 scanning electron microscope, operated at $20 \mathrm{kV}$. The image was digitally recorded and transferred to a computer for printing. 


\section{RESULTS}

\section{Description of hexamitids recovered from discus and angelfish}

Hexamitids were isolated from the intestine, kidney, liver, spleen, and head lesion of discus and from the intestine and head lesion of the angelfish. The morphological features of these flagellates as viewed by phase contrast microscopy were identical in all isolates. They have an elongated body ( 8 to $14 \mu \mathrm{m} \times 3$ to $6 \mu \mathrm{m}$ ) with 8 flagella, 6 anterior and 2 posterior ones (Fig. 1A). The 2 sigmoid shaped, elongate nuclei were clearly highlighted in Giemsa-stained preparations. The following features were observed at the ultrastructural level. Two lateral ridges originate at the anterior end of the flagellate and taper longitudinally down the length of the body, where they elaborately swirl across the posterior end to the opposite side and back again, passing into the flagella pocket (Fig. 1B,C). A prominent papilla is located on each trailing flagellum near the point of origin from the body (Fig. 1C).

\section{Survival of flagellates in in vitro culture}

Isolates of flagellates were successfully established and maintained in culture from the intestine, liver, kidney, spleen, and head lesion of discus and the intestine and head lesion of angelfish. Although all isolates were successfully sub-cultured, only 1 of each of the following were selected for long-term maintenance: discus intestine, discus head lesion or angelfish intestine. Isolates of discus intestine and head lesion were maintained through 6 sub-cultures over 29 d before being terminated at the conclusion of the project. Survival on sub-culture was greatly enhanced by agnotobiotic culture with the addition of fresh Oreochromis niloticus liver to the medium. Flagellates died within $10 \mathrm{~d}$ if not subcultured.
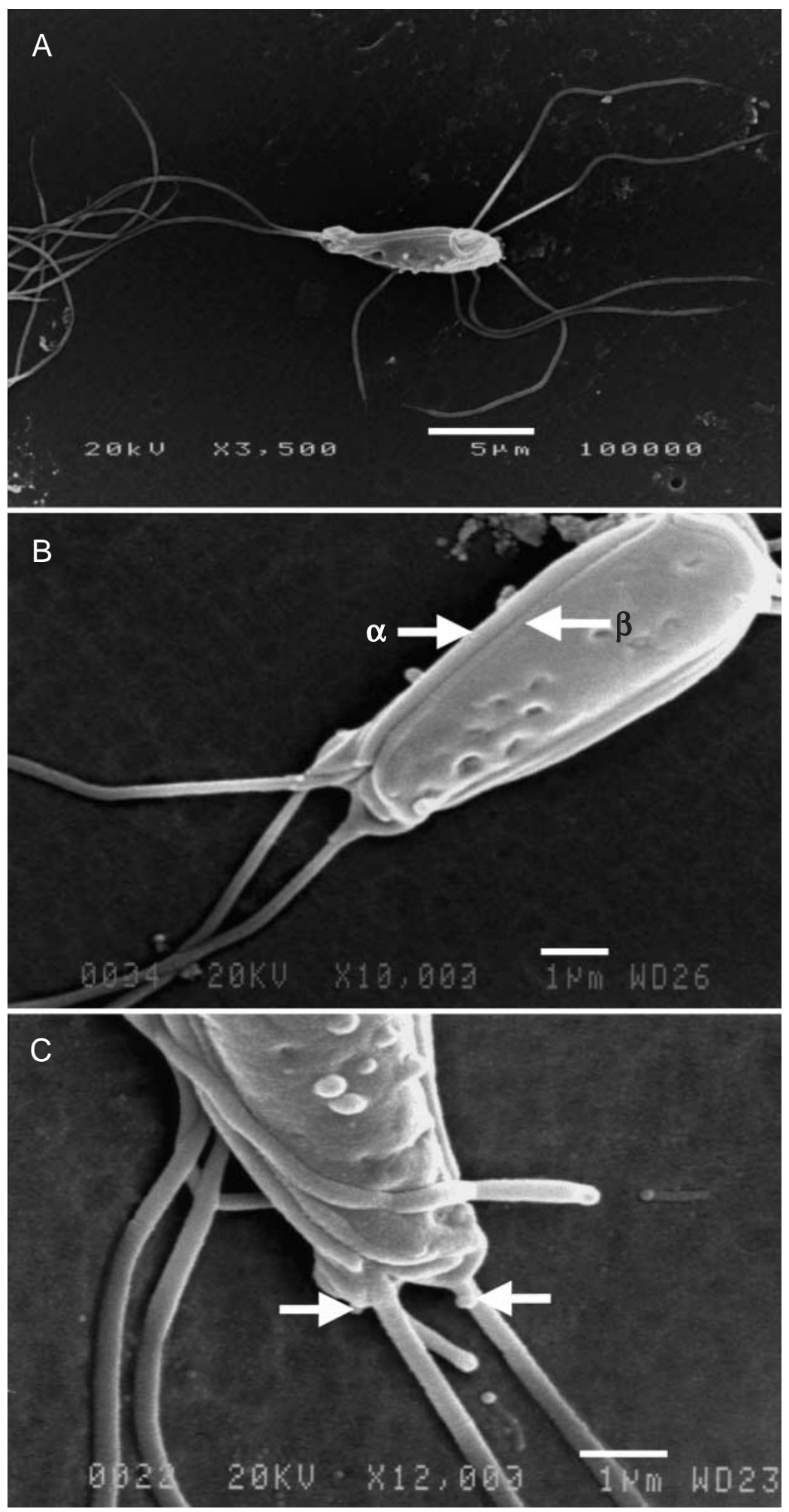

Fig. 1. SEM of Spironucleus vortens from head lesion of discus. (A) Note shape of body and arrangement of the 8 flagella, each of which taper terminally culminating in a small bulb. (B) Note prominent lateral compound ridge $(\alpha)$ and peripheral ridge $(\beta)$ extending the length of the body. (C) Posterior region of $S$. vortens. Note elaborate swirls of the peripheral ridge and papilla on the base of each terminal flagella (arrowed) 


\section{Growth of Spironucleus vortens in culture supple- mented with Oreochromis niloticus liver at $25^{\circ} \mathrm{C}$}

Samples $1 \mathrm{ml}$ of the head lesion isolate from discus were added to each of 5 bijou bottles containing $3 \mathrm{ml}$ of medium supplemented with fresh Oreochromis niloticus liver. The numbers of flagellates in each culture tube were then estimated and found to lie within a range of 465000 to $540000 \mathrm{ml}^{-1}$. Further estimates for each tube were taken at $24 \mathrm{~h}$ intervals over $7 \mathrm{~d}$ (Fig. 2).

No flagellate growth was detected for $24 \mathrm{~h}$, following which time the flagellates underwent exponential growth peaking at Day 4, when a maximum number were recorded at approximately $26700000 \mathrm{ml}^{-1}$. A rapid decline after Day 5 occurred with only $2400000 \mathrm{ml}^{-1}$ cells recorded by Day 7, a 10-fold decline.

\section{Recognisable signs of hole-in-the-head disease}

The 12 infected tropical fish showed different degrees of hole-in-the-head development. These were categorised into 2 groups, moderate and severe, according to the extent of the lesions and condition of fish. In all cases the lesions were confined chiefly to the head region, occasionally extending posterior along the lateral line. In moderate infections of the disease the lesions appeared to be bilaterally symmetrical on the head (Fig. 3), becoming more extensive and irregular in shape in severe infections with the possibility that adjacent lesions coalesce (Fig. 4). Splenomegaly was noted in systemic infections.

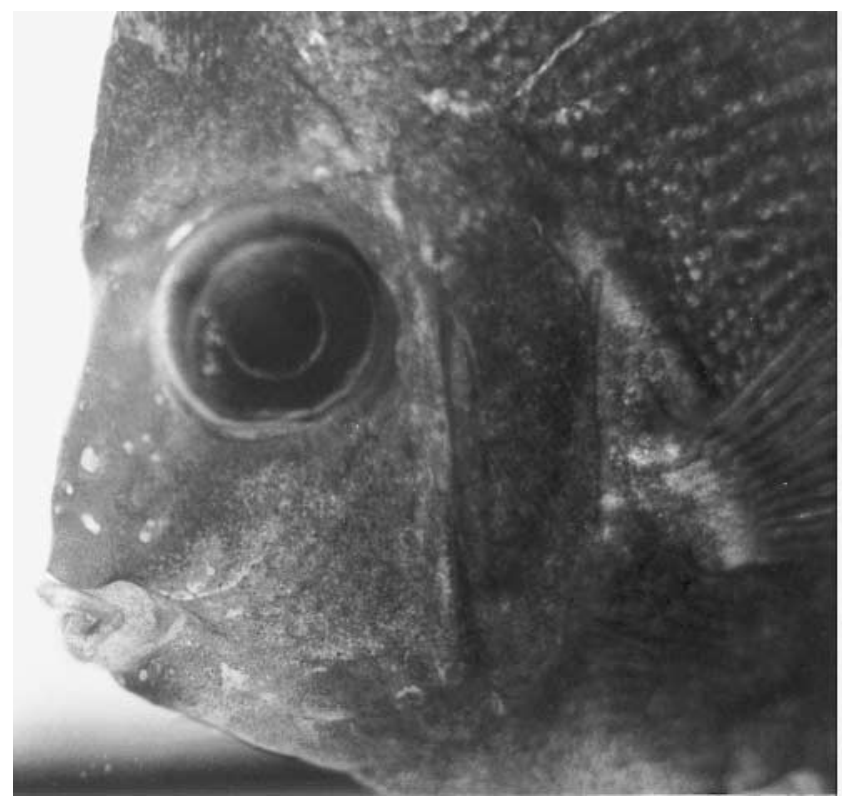

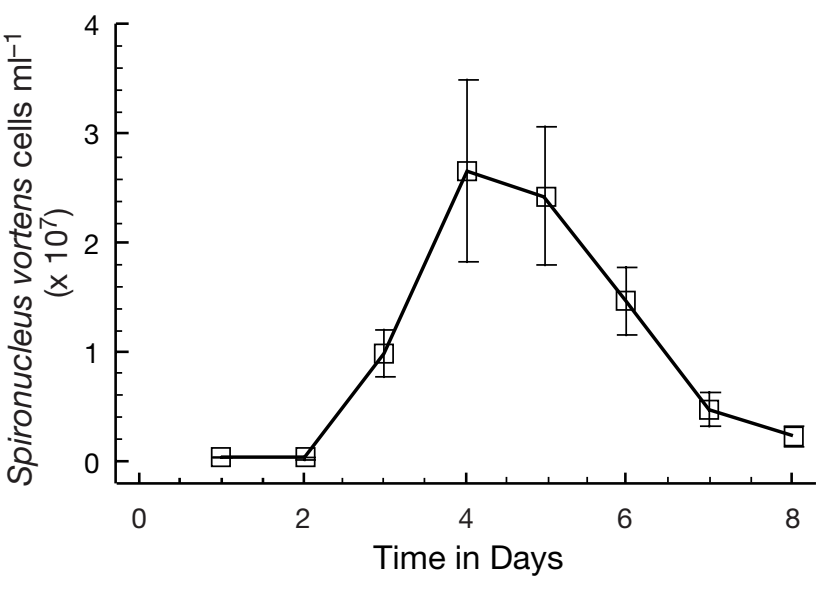

Fig. 2. Spironucleus vortens isolated from head lesion of discus. Mean growth rate of 5 replicate cultures in Eagle's MEM with $10 \%$ foetal bovine serum, bile salts $\left(150 \mathrm{\mu g}^{-1}\right)$ supplemented with Oreochromis niloticus liver. Antibiotics, including penicillin, streptomycin, gentamicin, and fungizone, at $1000 \mu \mathrm{g} \mathrm{ml}^{-1}$. Error bars $=\mathrm{SE}$

\section{DISCUSSION}

Hexamitids from the head lesions of angelfish and discus are here identified as Spironucleus vortens Poynton et al. 1995 on the basis of EM in comparison with specimens isolated from angelfish and discus intestine. The parasite $S$. vortens was also recorded from the liver, spleen, and kidney of discus, confirming the studies of Amlacher (1970) and Molnar (1974) concerning the systemic nature of this pathogen. Although Amlacher (1970) named the parasite Hexamita symphysodonis, Kulda \& Lom $(1964 \mathrm{a}, \mathrm{b})$ suggested that the

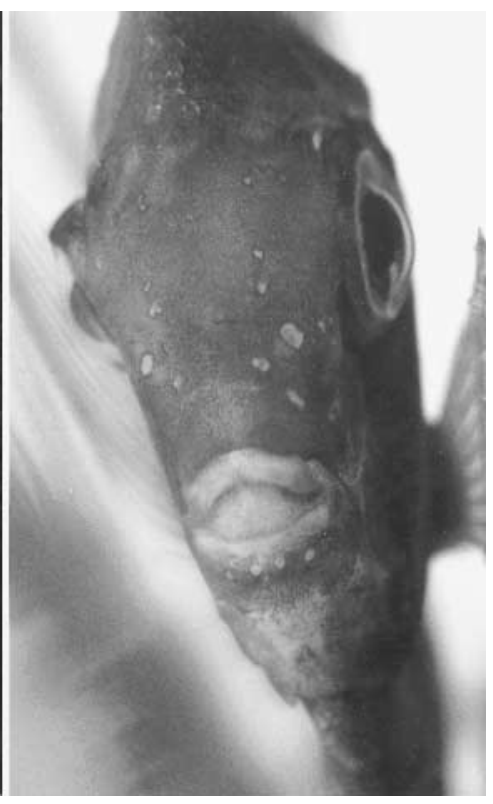

Fig. 3. Symphysodon discus. Photographs of a discus with moderate hole-in-the-head infection. (A) Side view. Small regular-shaped holes around the eyes and mouth. (B) Headon view of the same fish. Note bilaterally symmetrical holes 
Fig. 4. Pterophyllum scalare. Photograph of an angelfish with severe hole-in-thehead disease. Holes have expanded and coalesced, extending into the anterior region of the lateral line

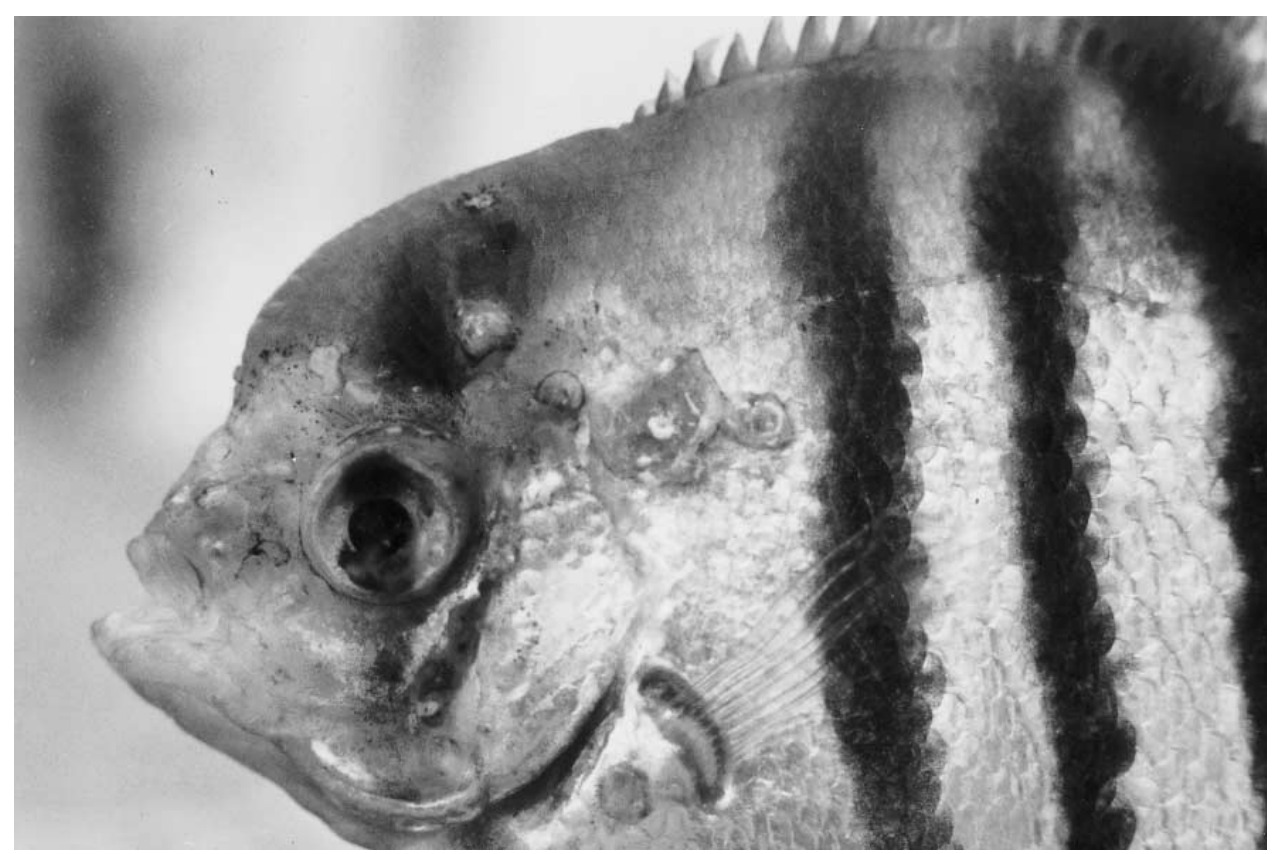

causative agent of hexamitosis of cichlids could be assigned to the genus Spironucleus. Woo \& Poynton (1995) recently reassessed the genus based on topographical features seen only with the aid of SEM. It now seems possible that some species of hexamitids from cichlids previously identified on the basis of light microscopy (Becker 1977, Bootsma 1977, Ferguson \& Moccia 1980, Gratzek 1988), including Hexamita salmonis, Moore 1922, recorded from skin lesions on cichlids (Nigrelli \& Hafter 1947), may now be included in Spironucleus.

Head lesions of fish demonstrating hole-in-the-head disease were always associated with the acoustic lateralis system in the present study. According to Herkner (1969, 1970), a heavy infection of Spironucleus (Hexamitidae) underneath the skin creates necrotic tissue and can cause the lateralis system to literally fall apart. The fact that $S$. vortens was also isolated from all head lesions examined here also supports the view of Bassleer (1983) that hexamitids cause the holes, either through direct infection of host tissue underneath the skin or indirectly by blocking the tiny blood vessels that supply the sensory system. The route of infection remains unknown, however, and we can only speculate as to whether hole-in-the-head disease represents the external manifestations of systemic infection via the gut or marks the initial site of invasion via the sensory system. In support of the former it might be significant that in the present study $S$. vortens was isolated from the intestine of all fish, including controls, and severe hole-in-the-head disease was always associated with infections of the liver, spleen and kidney. The parasite was absent from these latter organs in fish showing moderate or little disease severity; however, in these instances the infection appeared to be in a state of remission, with fish making a full recovery. Hexamitids are known to closely interact with the gut wall of fish; $S$. torosa can reportedly attach to the intestinal mucosa (Poynton \& Morrison 1990). Post (1983) and Poynton \& Morrison (1990) described an intracellular form of Hexamita salmonis undergoing multiple fission within epithelial cells of the intestine. Invasion of the lamina propria and entry of the hepatic portal system could explain the high level of $S$. vortens observed within the liver of discus in the present study. It is of interest that Siddal et al. (1992) considered species of Spironucleus to be unique in their ability to invade the mucosa and localise in other tissues, albeit in mice.

Whether or not bacteria play a role in hole-in-thehead disease remains uncertain. Molnar (1974) noted an absence of bacteria from internal organs of fish infected with hexamitids, whereas Ferguson (1989) considered bacteria as mere contaminants in hexamitosis of fish. Bacteria are known to be an essential component in the establishment of some protozoans in the gut lumen of their host, these trophic associates being replaced by host cells in tissue invading species (Robinson 1968). In this respect it might be significant that Spironucleus vortens was successfully maintained here in vitro with bacteria, whereas addition of Oreochromis niloticus tissue, specifically liver, into the cultures greatly enhanced the activity and abundance of the trophozoites. Such active affinity for host tissue in culture has only previously been observed by Poynton 
et al. (1995). What factors initiate tissue invasion in $S$. vortens remains unknown. Abnormal events within the gut, including physiological changes, have been associated with the establishment of hexamitid infections in trout (Kulda \& Lom 1964b). It seems probable, therefore, that poor husbandry leading to fish stress and immunosuppression may be a major factor in the expression of hole-in-the-head disease, a view supported by others (Becker 1977, Goldstein 1979, Bassleer 1983, Andrews et al. 1988, Ferguson 1989, Vickerman 1990).

Acknowledgements. We wish to thank the assistance provided by the following people: Stan McMahon for his help in locating, photographing and maintaining infected fish within the University aquarium; Andy Gray, Paul Griffiths and Devon Discus for supplying the ornamental fish used in this study; Dr R. Moate for his advice and assistance in undertaking the SEM; and Dr Sarah L. Poynton for providing advice concerning the identification of Spironucleus vortens.

\section{LITERATURE CITED}

Amlacher E (1970) Taschenbuch der Fischkrankheiten. Fischer Verlag, Jena (Translated by Conray DA, Herman RL: Textbook of fish diseases, Chap 8. TFH Publications, Hong Kong)

Andrews C (1990) The ornamental fish trade and fish conservation. J Fish Biol 37(Suppl A):53-59

Andrews C, Exell A, Carrington N (1988) The manual of fish health. Salamander Books Ltd, London

Bassleer G (1983) Disease prevention and control. Spironucleus/ Hexamita infection, hole-in-the-head disease. Freshw Mar Aquar 6:38-60

Becker CD (1977) Flagellate parasites of fish. In: Kreier JP (ed) Parasitic Protozoa, Vol 1. Academic Press, New York, p 357-416

Bootsma R (1977) Elseviers aquarium encyclopedia. Fish disease section. Elseviers Publication, Amsterdam

Brugerolle G, Joyon L, Oktem N (1973) Contribution à l'étude cytologique et phylétique des diplozoaires (Zoomastigophorea, Diplozoa, Dangeard 1910). II. Etude ultrastructurale du genre Spironucleus (Lavier 1936). Protistologica 9:495-502

Buchmann K, Uldal A (1996) Temperature, pH and bile dependent in vitro cultivation of Hexamita salmonis from rainbow trout Oncorhynchus mykiss intestine. Dis Aquat Org 24:169-172

Degen B (1996) Degen discus. TFH Publications Inc., Neptune City, NJ

Ferguson HW (1979) Scanning and transmission electron microscopy observations on Hexamita salmonis (Moore, 1922) related to mortalities in rainbow trout fry Salmo gairdneri Richardson. J Fish Dis 2:57-67

Editorial responsibility: Wolfgang Körting,

Hannover, Germany
Ferguson HW (1989) Systemic pathology of fish: a text and atlas of comparative tissue responses in diseases of teleosts. Iowa State University Press, Ames

Ferguson HW, Moccia RD (1980) Disseminated hexamitiasis in Siamese fighting fish. J Am Vet Med Assoc 177:854-857

Goldstein R (1979) Disease prevention and control. Freshw Mar Aquar, June:52-53

Gratzek JB (1988) Parasites associated with ornamental fish. Veterinary clinics of North America, small animal practice. Trop Fish Med 18:375-399

Herkner (1969) Lochkrankheit—ein unerschöpfliches Thema. Aquar Terr Z 22:344-348

Herkner (1970) Ergänzende Beobachtungen zum Thema Lochkrankheit. Aquar Terr Z 22:154-157

Kulda J, Lom J (1964a) Remarks on the diplomastigine flagellates from the intestine of fishes. Parasitology 54:753-762

Kulda J, Lom J (1964b) Spironucleus elegans Lavier, parasite of fish. Cesk. Parasitology 11:187-192

MacInnis AJ, Voge M (1970) Experiments and techniques in parasitology. WH Freeman \& Co, San Francisco

Molnar K (1974) Data on the 'Octomitosis' (spironucleosis) of cyprinids and aquary fishes. Acta Vet Acad Sci Hung 24: 99-106

Nigrelli RF, Hafter E (1947) A species of Hexamita from the skin of two cichlids. Anat Rec 99:683-684

Post GW (1983) Textbook of fish health. TFH Publications, Inc Ltd, Neptune City, NJ

Post GW (1987) Textbook of fish health, 2nd edn. TFH Publications, Inc Ltd, Neptune City, NJ

Poynton SL, Morrison C (1990) Morphology of diplomonad flagellates: Spironucleus torosa n. sp. from Atlantic cod Gadus morhua L., and haddock Melanogrammus aeglefinus (L.) and Hexamita salmonis Moore from brook trout Salvelinus fontinalis (Mitchill). J Protozool 37:369-383

Poynton S, Fraser W, Francis-Floyd R, Rutledge P, Reed P, Nerad T (1995) Spironucleus vortens n. sp. from the freshwater angelfish Pterophyllum scalare: morphology and Culture. J Eukaryot Microbiol 42(6):731-742

Robinson GL (1968) The laboratory diagnosis of human parasitic amoebae. Trans R Soc Trop Med Hyg 62(2): 285-294

Siddal ME, Hong H, Desser SS (1992) Phylogenetic analysis of the Diplomonadida (Wenyon, 1926) Brugerolle, 1975: evidence for heterochrony in protozoa and against Giardia lamblia as a 'Missing Link'. J Protozool 39:361-367

Sterud E, Mo TA, Poppe TT (1998) Systemic spironucleosis in sea-farmed Atlantic salmon Salmo salar, caused by Spironucleus barkhanus transmitted from feral Arctic char Salvelinus alpinus. Dis Aquat Org 33:63-66

Vickerman K (1990) Phylum Zoomastigina Class Diplomonadida. In: Margulis L, Corliss JO, Melkonian M, Chapman D (eds) Handbook of Protoctista. Jones \& Bartlett, Boston, MA, p 200-210

Woo PTK, Poynton SL (1995) Diplomonadida, Kinetoplastida and Amoebida (Phylum Sarcomastigophora). In: Woo PTK (ed) Fish diseases and disorders, Vol 1. Protozoan and metazoan infections. CAB International, Wallingford, p 27-96

Submitted: August 2, 2000; Accepted: December 10, 2000 Proofs received from author(s): June 25, 2001 